\title{
On Some Aspects of the Structure and Functions of the Wetlands of North Bihar, India
}

\author{
Sharma Rashmi Rani, Verma Rohit Kumar and Roy Surendra Prasad * \\ University Department of Zoology / Biotechnology, T.M. Bhagalpur Univeristy, Bhagalpur 812007, India \\ *Corresponding Author
}

Received: $10^{\text {th }}$ November, 2019

Accepted: $14^{\text {th }}$ January, 2020

Published online: $1^{\text {st }}$ March, 2020

https://doi.org/10.33745/ijzi.2020.v06i01.004

\begin{abstract}
Bihar has a rich wetland area and has high diversity among inhabiting species. Therefore conservation of these wetlands is necessary for protecting such diverse and unique species. Different physico-chemical parameters such as dissolved oxygen, alkalinity, presence of phytoplanktons and zooplanktons were analyzed in the present study in different types of swamps and wetland of Katihar, Purnea, Saharsa, Khagaria, Begusarai, Samastipur, Darbhanga, Madhubani, West and East Champaran, Sitamarhi, Vaishali, Siwan and Muzaffarpur. Each and every type of wetland was found to have variation within the parameters undertaken. Each and every wetland has their own unique condition and supports variable life forms.
\end{abstract}

Keywords: Bihar, Wetlands, Species, Physico-chemical, Life forms

Citation: Sharma Rashmi Rani, Verma Rohit Kumar and Roy Surendra Prasad: On Some Aspects of the Structure and Functions of the Wetlands of North Bihar, India. Intern. J. Zool. Invest. 6 (1): 49-57, 2020.

https://doi.org/10.33745/ijzi.2020.v06i01.004

\section{Introduction}

Gokce (2018) stated that "Wetlands are an ecosystem from mangrove to subarctic peatlands that have affected human". Wetlands (flood plains, marshes, swamps and chaurs) are one of those lentic waters which form links between terrestrial and aquatic ecosystems and play an important role in eutrophication. Such ecosystems will have a community structure intermediate between the open water and forest types and in such environment the autotrophic-heterotrophic stratification is very less. According to Odum (1962) the most productive ecosystems of the ecosphere are those in which autotrophic-heterotrophic strata lie close together, thus, ensuring efficient nutrient regeneration and 
recycling. Wetlands have been named as "Kidneys of the Earth" as according to Yu et al. (2019) "they provide important functions towards stabilizing the environment, longterm protection of water sources, effectively minimizing sediment loss, purifying surface water from industrial and agricultural pollutants, and enhancing aquifer recharge".

In the region of North-Bihar districts (Katihar, Purnea, Saharsa, Khagaria, Begusarai, Samastipur, Darbhanga, Madhubani, West and East Champaran, Sitamarhi, Vaishali, Siwan and Muzaffarpur) many such types of wetlands exist (Fig. 1). The eco-restoration of such wetlands for sustainable use of resources is of utmost significance. Therefore, the objective of present study is to investigate the structure and function of these wetlands and to explore the possibilities for their ecological restoration of denuded environment for their sustainable development for aquaculture and pisciculture.

\section{Materials and Methods}

Study area: The wetlands under study include three typical swampy wetlands of NorthBihar, that have been described in the text by the names of permanent (Doped), Makhana and Chaur swamps.

These three different types of swamps were selected for seasonal observations of certain physico-chemical factors of water. The first two swamps were perennial in nature while the third one was seasonal, as it completely dried up during summer months (March to July). The $\mathrm{pH}, \mathrm{DO}_{2}, \mathrm{FCO}_{2}, \mathrm{CO}^{--}$, $\mathrm{HCO}_{3}{ }^{-}$were studied every months for two years from January 2017 to December, 2018. Certain parameters like free $\mathrm{H}_{2} \mathrm{~S}, \mathrm{Si}^{-}$and $\mathrm{Cl}^{-}$content were analysed monthly. The physico- chemical factors were analyzed according to Welch (1948) and APHA (1981). The standing crops of periphyton, phytoplankton, zooplankton, macro-invertebrates and fishes were studied using different sampling devices and taxa were identified in the laboratory by the literature available in their respective fields.

\section{Results and Discussion}

The results of physico-chemical factors of the swamps under study are shown in Tables 1-3, respectively.

\section{Physico-chemical conditions of Swamps and Wetlands:}

Generally, there is higher dissolved oxygen and less $\mathrm{FCO}_{2}$ concentration in chaur swamps than in Makhana and doped swamps. Low $\mathrm{pH}$ of water together with high atmospheric and water temperatures, heavy accumulation of organic matter and hypoxic conditions of soils and water are responsible for the production of major decomposition products viz., hydrogen sulphide, methane, free ammonia, etc. in these wetlands. Gas envelops have been constructed for different types of swamps. Such envelops were represented graphically by plotting all the monthly measurements of $\mathrm{DO}_{2}$ and $\mathrm{FCO}_{2}$ within a particular swamp and enclosing these data with a polygon. More steep envelope in Makhana (Eurale ferox) swamps was evident of hypercarbic environment but it was flatter than the gas envelops of chaur swamp which was infested with emergent Cyperus reeds with a combination of sufficient submerged macrophytes. There was comparatively more $\mathrm{DO}_{2}$ and less $\mathrm{FCO}_{2}$ concentration in chaur swamp than Makhana and doped swamps. The concentrations of $\mathrm{FCO}_{2}$ in swamps control the pH, bicarbonate-carbonate alkalinities (Fig. 2). 


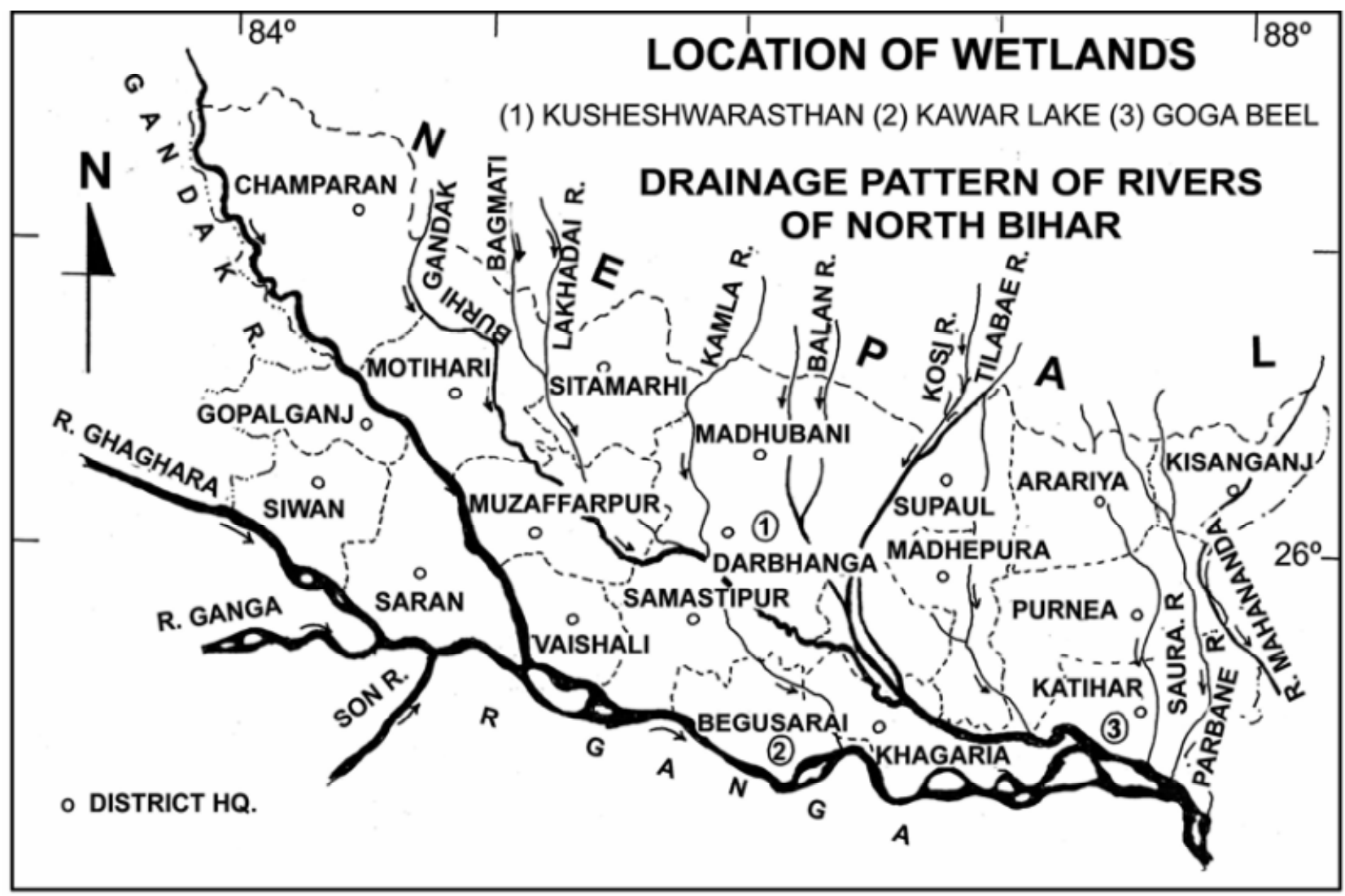

Fig. 1: Wetlands in districts of North-Bihar

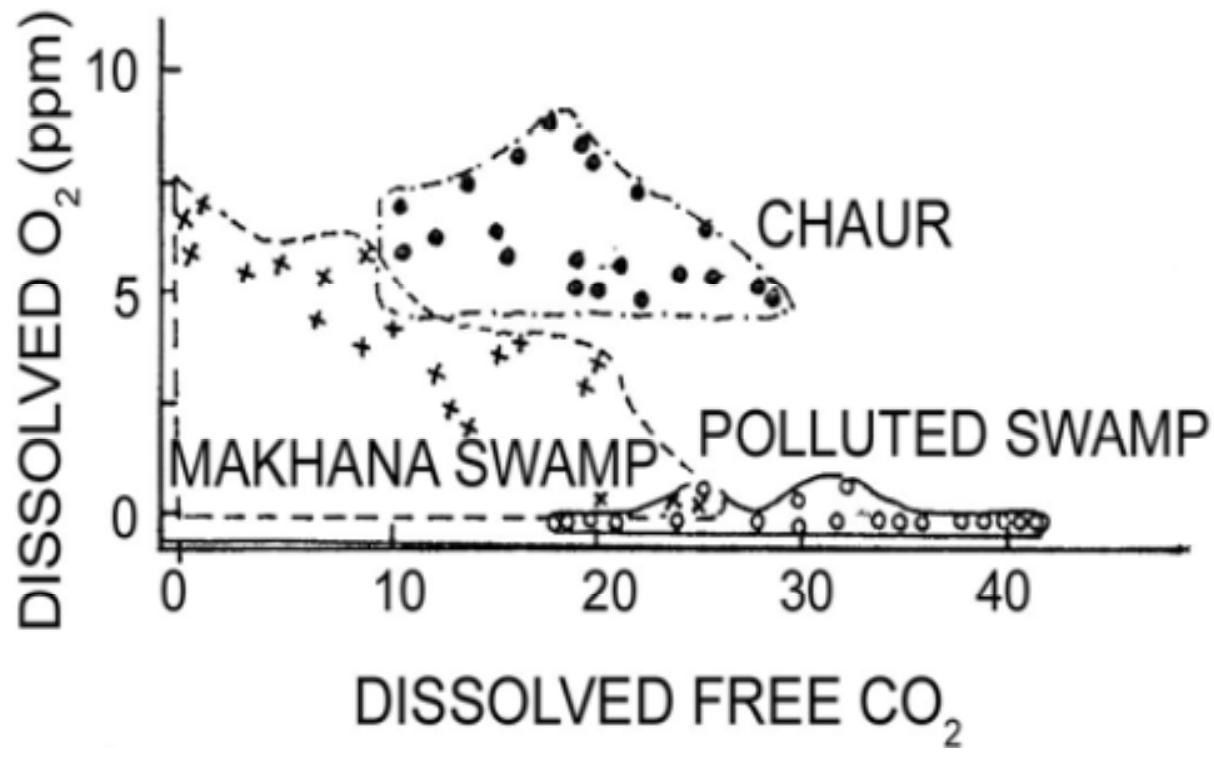

Fig. 2: Gas envelop of swamps and wetlands 
Table 1: Monthly variations of dissolved oxygen and free carbon dioxide in the waters of three wetlands of North-Bihar

\begin{tabular}{|c|c|c|c|c|c|c|}
\hline \multirow[b]{2}{*}{ Months } & \multicolumn{2}{|c|}{ Hyacinth Swamp } & \multicolumn{2}{|c|}{ Makhana Swamp } & \multicolumn{2}{|c|}{ Chaur Swamp } \\
\hline & $\begin{array}{l}\text { Dissolved } \mathrm{O}_{2} \\
\quad(\mathrm{mg} / \mathrm{L})\end{array}$ & $\begin{array}{c}\text { Free } \mathrm{CO}_{2} \\
(m g / L)\end{array}$ & $\begin{array}{l}\text { Dissolved } \mathrm{O}_{2} \\
\quad(\mathrm{mg} / \mathrm{L})\end{array}$ & $\begin{array}{c}\text { Free } \mathrm{CO}_{2} \\
(\mathrm{mg} / \mathrm{L})\end{array}$ & $\begin{array}{l}\text { Dissolved } \mathrm{O}_{2} \\
\quad(\mathrm{mg} / \mathrm{L})\end{array}$ & $\begin{array}{c}\text { Free } \mathrm{CO}_{2} \\
(m g / L)\end{array}$ \\
\hline \multicolumn{7}{|c|}{2017} \\
\hline Jan & 0.65 & 25.00 & 6.25 & 0.00 & 5.80 & 19.00 \\
\hline Feb. & 0.00 & 38.00 & 6.80 & 0.00 & 5.00 & 22.00 \\
\hline Mar. & 0.00 & 36.00 & 6.00 & 8.50 & & \\
\hline Apr. & 0.00 & 40.00 & 6.00 & 8.50 & & \\
\hline May & 0.00 & 39.00 & 0.30 & 24.00 & & \\
\hline Jun & 0.00 & 41.00 & 0.20 & 20.00 & & \\
\hline Jul. & 0.00 & 24.50 & 2.50 & 12.00 & & \\
\hline Aug. & 0.00 & 32.00 & 4.30 & 10.00 & 5.25 & 28.00 \\
\hline Sep. & 0.00 & 30.00 & 3.25 & 12.00 & 6.50 & 25.25 \\
\hline Oct. & 0.00 & 28.00 & 3.85 & 8.50 & 5.20 & 20.00 \\
\hline Nov. & 0.00 & 24.00 & 5.50 & 2.50 & 7.00 & 10.30 \\
\hline Dec. & 0.53 & 30.00 & 6.00 & 0.00 & 6.45 & 12.00 \\
\hline \multicolumn{7}{|c|}{2018} \\
\hline Jan & 0.82 & 32.50 & 6.45 & 0.00 & 6.00 & 10.50 \\
\hline Feb. & 0.00 & 35.00 & 6.90 & 0.56 & 5.50 & 24.00 \\
\hline Mar. & 0.00 & 34.00 & 5.80 & 4.50 & & \\
\hline Apr. & 0.00 & 35.00 & 5.50 & 6.50 & & \\
\hline May. & 0.00 & 35.00 & 2.00 & 13.50 & & \\
\hline Jun. & 0.00 & 40.50 & 0.85 & 18.00 & & \\
\hline Jul. & 0.00 & 25.00 & 0.50 & 25.00 & 5.00 & 28.50 \\
\hline Aug. & 0.00 & 22.00 & 3.55 & 20.00 & 5.50 & 25.50 \\
\hline Sep. & 0.00 & 20.00 & 3.00 & 19.50 & 6.50 & 15.00 \\
\hline Oct. & 0.00 & 28.50 & 3.85 & 15.60 & 6.00 & 15.65 \\
\hline Nov. & 0.00 & 21.00 & 3.90 & 16.00 & 5.75 & 21.00 \\
\hline Dec. & 0.25 & 25.00 & 4.50 & 6.50 & 8.85 & 18.50 \\
\hline
\end{tabular}


Table 2: Monthly variations of $\mathrm{HCO}_{3}{ }^{-}, \mathrm{CO}_{3}{ }^{-}$and $\mathrm{pH}$ of water in three tropical wetlands of North-Bihar

\begin{tabular}{|c|c|c|c|c|c|c|c|c|c|}
\hline \multirow[b]{2}{*}{ Months } & \multicolumn{3}{|c|}{ Hyacinth Swamp } & \multicolumn{3}{|c|}{ Makhana Swamp } & \multicolumn{3}{|c|}{ Chaur Swamp } \\
\hline & $\begin{array}{c}\mathrm{HCO}_{3^{-}} \\
(\mathrm{mg} / \mathrm{L})\end{array}$ & $\begin{array}{c}\mathrm{CO}_{3^{-}} \\
(\mathrm{mg} / \mathrm{L})\end{array}$ & $p H$ & $\begin{array}{c}\mathrm{HCO}_{3^{-}} \\
(\mathrm{mg} / \mathrm{L})\end{array}$ & $\begin{array}{c}\mathrm{CO}_{3^{-}} \\
(\mathrm{mg} / \mathrm{L})\end{array}$ & $p H$ & $\begin{array}{c}\mathrm{HCO}_{3^{-}} \\
(\mathrm{mg} / \mathrm{L})\end{array}$ & $\begin{array}{c}\mathrm{CO}_{3^{-}} \\
(\mathrm{mg} / \mathrm{L})\end{array}$ & $p H$ \\
\hline \multicolumn{10}{|c|}{2017} \\
\hline Jan. & 100.00 & 7.8 & 120.00 & 2.50 & 8.1 & 95.00 & 0.0 & 8.0 & \\
\hline Feb. & 104.00 & 7.8 & 101 & 3.80 & 9.0 & 85.00 & 0.0 & 7.9 & \\
\hline Mar. & 106.00 & 7.5 & 150.00 & & 7.5 & & & & \\
\hline Apr. & 115.00 & 7.5 & 150.00 & & 7.5 & & & & \\
\hline May. & 294.00 & 7.7 & 230.00 & & 7.0 & & & & \\
\hline Jun. & 360.00 & 7.2 & 245.00 & 7.1 & & & & & \\
\hline Jul. & 324.00 & 7.8 & 192.00 & & 7.0 & & & & \\
\hline Aug. & 80.00 & 7.9 & 140.00 & & 7.5 & 79.50 & & 7.5 & \\
\hline Sep. & 78.00 & 7.3 & 159.00 & & 7.7 & 78.50 & & 7.7 & \\
\hline Oct. & 115.00 & 7.2 & 135.00 & & 7.8 & 64.00 & & 7.5 & \\
\hline Nov. & 81.00 & 7.5 & 100.00 & & 7.9 & 50.00 & & 7.5 & \\
\hline Dec. & 97.00 & 7.8 & 115.00 & 3.80 & 8.1 & 52.00 & & 7.6 & \\
\hline \multicolumn{10}{|c|}{2018} \\
\hline Jan. & 98.00 & 7.6 & 115.00 & 3.50 & 8.5 & 82.00 & & 7.9 & \\
\hline Feb. & 110.00 & 7.6 & 120.00 & & 8.0 & 80.50 & & 7.9 & \\
\hline Mar. & 112.00 & 7.5 & 192.00 & & 8.0 & & & & \\
\hline Apr. & 118.00 & 7.6 & 155.00 & & 7.9 & & & & \\
\hline May. & 115.00 & 7.5 & 160.00 & & 7.8 & & & & \\
\hline Jun. & 116.00 & 7.3 & 197.00 & & 7.3 & & & & \\
\hline Jul. & 109.00 & 7.2 & 204.00 & & 7.3 & 70.00 & & 7.6 & \\
\hline Aug. & 90.00 & 7.2 & 195.00 & & 7.2 & 71.00 & & 7.6 & \\
\hline Sep. & 94.00 & 7.2 & 175.00 & & 7.2 & 78.50 & & 7.7 & \\
\hline Oct. & 96.00 & 7.5 & 132.00 & & 7.5 & 75.00 & & 7.6 & \\
\hline Nov. & 98.00 & 7.5 & 120.00 & & 7.5 & 75.00 & & 7.6 & \\
\hline Dec. & 98.00 & 7.5 & 107.00 & & 7.6 & 76.50 & & 7.7 & \\
\hline
\end{tabular}


Table 3: Monthly variations in the free Hydrogen Sulphide, Chloride and Silicate in the three tropical wetlands of North Bihar

\begin{tabular}{|c|c|c|c|c|c|c|c|c|c|}
\hline \multirow{3}{*}{ Months } & \multicolumn{3}{|c|}{ Hyacinth Swamp } & \multicolumn{3}{|c|}{ Makhana Swamp } & \multicolumn{3}{|c|}{ Chaur Swamp } \\
\hline & $\begin{array}{c}\mathrm{H}_{2} \mathrm{~S} \\
(\mathrm{mg} / \mathrm{L})\end{array}$ & $\begin{array}{c}\text { Chloride } \\
(\mathrm{mg} / \mathrm{L})\end{array}$ & $\begin{array}{c}\text { Silicate } \\
(\mathrm{mg} / \mathrm{L})\end{array}$ & $\begin{array}{c}\mathrm{H}_{2} \mathrm{~S} \\
(\mathrm{mg} / \mathrm{L})\end{array}$ & $\begin{array}{c}\text { Chloride } \\
(\mathrm{mg} / \mathrm{L})\end{array}$ & $\begin{array}{c}\text { Silicate } \\
(\mathrm{mg} / \mathrm{L})\end{array}$ & $\begin{array}{c}\mathrm{H}_{2} \mathrm{~S} \\
(\mathrm{mg} / \mathrm{L})\end{array}$ & $\begin{array}{c}\text { Chloride } \\
(\mathrm{mg} / \mathrm{L})\end{array}$ & $\begin{array}{c}\text { Silicate } \\
(\mathrm{mg} / \mathrm{L})\end{array}$ \\
\hline & \multicolumn{9}{|c|}{2017} \\
\hline July & 3.90 & 1.90 & & 1.45 & 1.50 & & & & \\
\hline Aug. & 4.60 & 1.75 & & 2.52 & 1.50 & & 1.50 & 0.40 & \\
\hline Sep. & 4.00 & 1.65 & & 2.50 & 1.50 & & 2.20 & 0.40 & \\
\hline Oct. & 3.50 & 1.65 & & 2.25 & 1.50 & & 0.00 & 0.30 & \\
\hline Nov. & 2.15 & 1.60 & & 1.20 & 1.55 & & 1.50 & 0.35 & \\
\hline Dec. & 2.00 & 1.65 & & 1.09 & 0.55 & & 1.62 & 0.35 & \\
\hline \multicolumn{10}{|c|}{2018} \\
\hline Jan. & 2.45 & 1.50 & 45.5 & 0.85 & 0.55 & 36.0 & 1.00 & 0.40 & 35.5 \\
\hline Feb. & 3.68 & 1.55 & 45.0 & 0.95 & 0.50 & 34.0 & 1.35 & 0.45 & 30.0 \\
\hline Mar. & 4.05 & 2.05 & 48.0 & 0.55 & 0.75 & 34.5 & & & \\
\hline Apr. & 3.00 & 2.05 & 51.0 & 1.65 & 0.92 & 32.0 & & & \\
\hline May. & 4.56 & 2.00 & 56,0 & 3.05 & 1.05 & 38.0 & & & \\
\hline Jun. & 4.92 & 1.80 & 54.00 & 3.31 & 1.00 & 38.5 & & & \\
\hline Jul. & 4.62 & 1.85 & 52.0 & 3.00 & 0.85 & 40.5 & 1.60 & 0.50 & 32.0 \\
\hline Aug. & 5.25 & 1.70 & 52.0 & 1.54 & 1.25 & 45.0 & 1.50 & 0.50 & 36.5 \\
\hline Sep. & 3.85 & 1.55 & 58.0 & 2.50 & 0.75 & 46.0 & 1.95 & 0.45 & 42.0 \\
\hline Oct. & 3.50 & 1.50 & 58.0 & 2.50 & 0.70 & 45,5 & 1.80 & 0.48 & 45.0 \\
\hline Nov. & 3.00 & 1.50 & 56.0 & 1.25 & 0.53 & 45.0 & 1.85 & 0.40 & 46.0 \\
\hline Dec. & 2.80 & 1.50 & 46.0 & 1.00 & 0.53 & 35.0 & 1.50 & 0.42 & 38.0 \\
\hline
\end{tabular}


In such systems only air-breathers and supplemental air-breathers are colonized, because of low $\mathrm{DO}_{2}$ contents and high amount of $\mathrm{FCO}_{2}$. Therefore, autotrophic biomass exceeds heterotrophic production in these environments. As such there is accumulation of autotrophic production in the system showing successional stage from aquatic to terrestrial environments (Roy, 2007). In chaur swamp the shape of the envelope was vertically steep showing higher $\mathrm{DO}_{2}$ content and lower $\mathrm{FCO}_{2}$ content while in doped swamps the shape was horizontally flatter showing lower $\mathrm{DO}_{2}$ content and higher $\mathrm{FCO}_{2}$ content in such environment. The Makhana swamp was intermediate between doped and chaur.

\section{Biotic components:}

The biotic components mainly include macrophytes, phytoplankton. periphyton, zooplankton, macro-invertebrates, airbreathing fishes, mollusces, crabs and migratory as well as local birds.

(a) Periphyton: The periphyton communities of the swamps mainly include algae and testaceous rhizopods (e.g., Euglypha, Diffugia, Centropyxis, Arcella etc.). Usually the periphytic species prefer highly eutrophic conditions with rich $\mathrm{DO}_{2}$, high $\mathrm{pH}$ and more alkaline medium (Brown and Austin, 1973). Hard testaceous shells of rhizopods were mainly composed of fine sand particles of silica and decomposed diatoms cells. The abundance of Bacillariophyceae and silicate contents of water thus, control the testaceous rhizopod population. (b) Phytoplankton: The phytoplankton communities of swamps were mainly represented by three groups of algae:

(i) Cyanophyceae (blue-green algae)

(ii) Chlorophyceae (green algae)

(iii) Bacillariophyceae (diatoms)

Bacillariophyceae dominated among the phytoplanktonic communities throughout the year.

(c) Zooplankton : Zooplankton communities of swamps belonged to Rotifera, Cladocera, Ostracopoda and Copepoda. The rotiferan population always dominate over other zooplankton communities in swamps.

(d) Macrophytes: There is general agreement that the fresh water swamps have higher macrophytic productivities than any other natural community (Leith, 1975; Thompson, 1975). The ratio of $P / R>1$, showing autotrophic community and such environments are on the way of succession (Singh, 1992).

Four characteristic vegetational communities were recognized in swamps. These are: (i) free floating type e.g., Eichhornia crassipus, Trapa bispinosa (ii) bottom rooted floating type e.g., Euryale ferox (iii) submerged type e.g., Hydrilla verticillata, Potamogeton crispus, Najas graminea, Ceratophyllum demursum etc. and (iv) emergent type e.g., Cyperus sp (Singh, 1992).

(e) Macro-invertebrate diversity: The macroinvertebrates fauna belong to three invertebrate phyla: (i) Annelida (ii) Mollusca (iii) (Arthropoda). 
Comparative studies on annual averages of total number and percentage of macroinvertebrates per meter square area in different swamps revealed that the Makhana swamp form the most favourable habitat for annelids, molluscs and insects. (Roy, 2007; Roy et al., 2008).

\section{Eco-restoration of doped swamps:}

Doped swamps are rich in nutrients and have immense potential energy source, which can be tapped for maximum energy return through detritivore fishes. Fishes feeding on different trophic levels provide enough scope for energy manipulations. 'The release and deposition of organic matters after death and decay of macrophytes, contributed significantly to the richness of the bottom soil of doped swamps. The low concentration of nutrients in the water phase may be due to the locking of nutrients for longer period by macrophytes. In water bodies the energy fixation at primary level is contributed both by phytoplankton and macrophytes In the wetlands the abundance and dominance of macrophytes favour detritus production.

Kumar (2007) has suggested that the water bodies with profuse aquatic macrophytes decompose and silt get deposited at the bottom after their death, which play an important role in the aquatic food web. These water bodies have very high rate of detritus production. Thus, the doped swamps can be restored by manipulating detritus feeder fishes in these environments.

\section{Conclusion}

It can be concluded that -(i) Wetlands are unstable ecosystems where $\mathrm{P} / \mathrm{R}>1.0$; (ii) They may change with season, rate of siltation and nutrient flux; (iii) They are on the way of succession; (iv) There is operation of complex hydrological and biogeochemical cycle; (v) Due to siltation, eutrophication of wetlands and human habitations surrounding the water systems, there is terrestrialisation of the large wetlands and chaurs in the region of NorthBihar; (vi) For water shed management, a series of reservoirs and canals are to be constructed in the upper reaches of the rivers for the control of flood as well as drought; (vii) Integrated aquaculture programme will help in conservation of these wetlands; (viii) Ecofriendly and eco-tourism programmes will be useful for the conservation and management of the wetlands of Bihar.

\section{References}

APHA (1981): American Public Health Association, Washington DC., pp. 1193.

Brown SD and Austin A P. (1973) Spatial and Temporal variation in Periphyton and Physico-chemical conditions in the littoral of a lake. Arch, Hydrobiol, 71: 183-232.

Gokce D. (2018) Wetland importance and management, wetlands management - assessing risk and sustainable solutions, IntechOpen, DOI: 10.5772/ intechopen.82456.

Kumar D. (2007) Fish and Fisheries of Kharagpur Lake. $\mathrm{Ph}$. D. Thesis, T. M. Bhagalpur University, Bhagalpur.

Lieth H. (1975) Primany productivity of the major vegetation units of the world . In: "Primary Production of Biosphere". Ed., H Lieth and RH Whittaker, Springer-Verlag pp. 203-216.

Odum EP. (1962) Structure and Fuction of Ecosystem. Presidential Address, Japanese Ecological Society, Tokyo (Japan).

Roy SP. (2007) Wetland of North-Bihar. Invited Articles for "Management Issues and Conservation Strategies". National Conference on Wetlands, Science and Society - An Assessment of their Integration. Dept. of Botany, Delhi University, Dec. 11-13.

Roy SP, Ramanand R, Prabhakar AK and Singh JP. (2008) Sustainable Development of Kawar Lake, Begusarai (North-Bihar) India. Eds: Sengupta, M. 
and Dalwani, R., Proc. of Taal, 2007: The $12^{\text {th }}$ World Lake Conference, 2033-2038.

Singh JP. (1992) Studies on some aspects of the Ecology of the Birds of Pakchhee Vihar Kawar Lake, Begusarai (North-Bihar). Ph.D. Thesis, T. M. Bhagalpur University, Bhagaipur.

Thompson K. (1976) Swamps development in the head water of white Nile. In: "The Nile; biology of an ancient river" Ed: J Rozoska. Dr. W. B. Junk Publishers. The Netherland.
Welch PS. (1948) Limnological methods. McGraw Hill Book Co. New York.

Yu H, Li L, Zhu W, Piao D, Cui G, Kim M, Jeon SW and Lee WK. (2019). Drought monitoring of the wetland in the Tumen River Basin between 1991 and 2016 using Landsat TM/ETM+. International Journal Remote Sensing 40: 1445-1459. 